\title{
Dielectric and electric conductivity studies of some pyrimidine compounds and their complexes
}

\author{
MS Masoud ${ }^{1 *}$, M Sh Ramadan ${ }^{1}$, A El-Samahy ${ }^{2}$, I Mahmoud ${ }^{2}$ and M H Al-Saify ${ }^{3}$ \\ ${ }^{1}$ Chemistry Department, Faculty of Science, Alexandria University, Alexandria, Egypt \\ ${ }^{2}$ Physics Department, Faculty of Science, Alexandria University, Alexandria, Egypt \\ ${ }^{3}$ Sidi Kerir Petrochemicals Company, Alexandria, Egypt
}

\begin{abstract}
The values of the dielectric constant $(\varepsilon)$, the loss tangent (tan ) and the electrical conductivity $(\sigma)$ for solutions of ligands barbituric acid(BA),5-nitrobarbituric acid(NBA) in $50 \%(\mathrm{v} / \mathrm{v}) \mathrm{MeOH}$-water also the ligands phenobarbital(PB) and thiouracil(TU) in $50 \%(\mathrm{v} / \mathrm{v})$ dioxane - water, all at $25^{\circ} \mathrm{C}$, in most cases, are decreased by decreasing the concentration. The $\ln \varepsilon$-T relationship for solutions of ligands and their complexes pointed to an increase of dielectric constant values with temperature. The presence of hydrogen bonding referred to cooperative reinforcement of dipole fields. NBA has a higher dielectric constant value than BA due to the presence of the electron withdrawing nitro group with large orientational polarization. PB has a lower dielectric constant value than TU since $\varepsilon$ decreases as the steric hindrance effect increases. For the complexes, the dielectric constant $(\varepsilon)$ values, are higher than that for the ligands. As the atomic number of the metal increases, the dielectric constant $(\varepsilon)$ and the loss tangent $(\tan \delta)$ are mostly decreased to block the charge distribution. The derived values of electrical conductivity that derived from $\grave{\varepsilon}$ and $\tan \delta$ data are regularly decreased and the activation energy $(\Delta \mathrm{E})$ of the complexes decreased in an irregular trend. The loss tangent (tan $\delta$ ) increases by increasing the temperature due to a decrease in viscosity, which exerts an increase of the dipole rotation and the polarization of the material. The molar conductance $\Lambda_{\mathrm{m}}$ for the electrolytic solutions of BA, NBA, PB and TU at $25^{\circ} \mathrm{C}$ are increased by decreasing the concentration. The BA, PB and TU ligands are of weak electrolytic nature, while NBA is of strong electrolytic behavior. However, the $\Lambda_{\mathrm{m}}$ values for solutions of ligands and their complexes are increased by increasing both temperature and dielectric constant due to the increase of the ionic mobility.
\end{abstract}

\section{Introduction}

The principle difference in the dielectric behavior of liquids and solids from the restriction of orientation of polar molecules usually caused in the solid state by lattice forces [1]. This restriction normally reduces or eliminates the orientation polarization and consequently, reduces the dielectric constant. In some liquids, dipolar molecules have been found to possess dielectric constants comparable to those in the solid state in which the molecules have sufficient orientational freedom. The relaxation time is interpreted as the average time which a molecule spends in one of the equilibrium position before jumping to the other one. This relaxation is exponential depends on temperature as well as the activation energy. For electrolytes and liquids of good electrical conductivity, the characteristic parameter is the variation of the conductivity with the change of the composition of the solution. The dielectric conductivity sums overall dissipative effects, which may represent the conductivity caused by migrating charge carrier and related to an energy [2] loss associated with a frequency dependence of dielectric. The electrolytic conductors have a transfer of material associated with the passage of an electric current in the solution. In this field, Masoud et al. [3-10] published a series of papers. The aim of this work to join all of the above parameters for the former ligands when associated with some metals to form complexes at different temperatures.

\section{Experimental}

\section{Dielectric and electrical conductivity measurements}

The UNIVERSAL DIELECTROMETER instrument (Type OH 301 [Hungary]) was used to measure dielectric constant $(\varepsilon)$ and loss tangent $(\tan \delta)$ for the different solutions of ligands BA NBA, and their complexes of metal ions $\left(\mathrm{Fe}^{3+}, \mathrm{Co}^{2+}, \mathrm{Cu}^{2+}\right.$ and $\left.\mathrm{Zn}^{2+}\right)$. Ligands dissolved in $50 \% \mathrm{v} / \mathrm{v} \mathrm{MeOH}$-water or also the ligands $\mathrm{PB}$ and $\mathrm{TU}$ were dissolved in $50 \% \mathrm{v} / \mathrm{v}$ dioxane-water media. The measurement were carried out at a frequency of $3 \mathrm{MHz}$ and at temperature range $\left(25-50^{\circ} \mathrm{C}\right)$. The temperature was controlled by a thermostat to $\pm 0.5^{\circ} \mathrm{C}$.

The measuring capacitance $C_{1}$ of the cell was calculated from the relation [11]:

$$
\begin{aligned}
& C_{1}=\frac{\mathrm{C}_{3}^{\prime}-C_{3}}{\varepsilon-1} \\
& \mathrm{C}_{3} \text { : The capacitance of empty measuring cell. }
\end{aligned}
$$

$\mathrm{C}_{3}^{\prime}$ : The capacitance of measuring cell filled with the calibrating liquid (50\% (v/v) dioxane-water and 50\% (v/v) MeOH-water, where $\varepsilon$ is the dielectric constant of the calibrating liquid. The stray capacitance $\mathrm{C}_{2}$ was calculated from the relation:

$$
\mathrm{C}_{2}=\mathrm{C}_{3}-\mathrm{C}_{1}
$$

The glass tap was opened (after calibration) to drain the liquid from the cell. The cell was removed from the apparatus, then cleaned and dried thoroughly.

Correspondence to: MS Masoud, Chemistry Department, Faculty of Science, Alexandria University, Alexandria, Egypt, E-mail: drmsmasoud@yahoo.com

Key words: Dielectric constant, loss tangent, ligand complexes, electrical conductivity and activation energy

Received: November 25, 2017; Accepted: December 26, 2017; Published: December 30, 2017 
The dielectric constant of the solution to be measured was calculated from the relationship [11]:

$\varepsilon=\frac{\mathrm{C}_{3}^{\prime \prime}-C_{2}}{C_{1}}$

$\mathrm{C}_{3}^{\prime \prime}$ : Overall capacitance of the cell filled with the test solution.

The loss tangent of the test solution was calculated from the relation [11]:

$\tan \delta=\frac{530 G}{C} \times 10^{-4}$

where: $\mathrm{C}(\mathrm{pF})=\mathrm{C}_{3}^{\prime \prime}-\mathrm{C}_{2}$

$\mathrm{G}(\mu \mathrm{S})=\mathrm{G}_{2}-\mathrm{G}_{1}$

$\mathrm{G}_{1}$ : Conductance of the empty cell. $\mathrm{G}_{2}$ : Conductance of the cell filled with the test solution.

\section{Molar conductance $\Lambda_{\mathrm{m}}$ measurements}

The conductivity of different concentrations of different ligands and metal complexes at different temperatures $\left(25-45^{\circ} \mathrm{C}\right)$ were carried out with Jenway 4010 conductivity meter instrument. The conductivity cell consists of a $150-\mathrm{ml}$ water-jacketed vessel fit with a polyethylene stopper in which appropriately located hole was used to insert a conductivity meter electrode (cell constant $\mathrm{K}=0.99 \mathrm{~cm}^{-1}$ at $25^{\circ} \mathrm{C}$ ), the molar conductances were calculated. The solution in the conductivity cell had the desired temperature control by using a thermostatic Techne model U10.

\section{Results and discussion}

The ligands under investigation are considered to be shown as in the Figure 1.

The dielectric constant is expressed as [11]:

$$
\varepsilon=\frac{\mathrm{C}}{\mathrm{C}_{\mathrm{o}}}
$$

C: The capacitance of a capacitor in which a dielectric material is inserted.

\section{$\mathrm{C}_{\mathrm{o}}$ : The capacitance of a capacitor in a vacuum.}

Changes of quality and composition of the dielectric material cause the dielectric constant to vary. The variations may be measured through the variation of the capacitance of the capacitor. For the characteristics of a capacitor it's connected to an alternating current circuit between whose plates there is a vacuum (loss free capacitor). A phase shift $\theta$ $=90^{\circ}$ will be produced between current and voltage. The capacitor behaves like a reactive resistance (reactance) in which no energy loss can occur.

From the relationship of alternating currents, the output is zero in case of $\theta=90^{\circ}$.

$$
\mathrm{W}=\mathrm{I} \times \mathrm{V} \times \cos \theta
$$

Where $\mathrm{W}$ is the heat developed per second in unit cube of the material, I is the current density and $\mathrm{V}$ is the voltage gradient.

If air is removed from the capacitor and a dielectric is inserted between the plates, the capacitor becomes lossy which may be considered as one with a resistor connected in series with it. Therefore, the phase shift between voltage and current becomes less than $90^{\circ}$. The capacitor takes up energy from the circuit, the energy is transformed into heat and a dielectric heat loss is produced. This is usually indicated as the tangent of the complement of the angle of the phase shift $(\theta)$, termed loss tangent $(\tan \delta)$, which could be determined from the relationship [12]:

$$
\tan \delta=\frac{\mathrm{G}}{\grave{\mathrm{u}} \times \mathrm{C}}
$$

where $\mathrm{G}=$ loss conductance, $\omega=$ angular frequency and $\mathrm{C}=$ capacitance.

Besides $\varepsilon, \tan \delta$ is another useful electro-physical constant which gives information on the composition of a material sometimes even more reliable than that derived from the dielectric constant. The dielectric constant $(\varepsilon)$ and loss tangent $(\tan \delta$ ) depend on many factors [13], such as the frequency of the applied voltage, temperature, concentration, etc.

In most cases both factors are decreased by decreasing the concentration. The change of $\varepsilon$ with temperature for the organic solvents can be expressed by the equation [14]:

$$
\varepsilon=\mathrm{a} \mathrm{e}^{\mathrm{bT}}
$$

where $\mathrm{a}$ and $\mathrm{b}$ are empirical constants, and $\mathrm{T}$ is the absolute temperature. This equation has been tested using a number of series of ligands and their complexes solutions. The values of $\varepsilon$ and $\tan \delta$ for solutions of ligands and their complexes at different temperatures (25$50^{\circ} \mathrm{C}$ ) are given in Table 1 . The dielectric constant increases mainly with increasing temperature due to the presence of hydrogen bonding which pointed to cooperative reinforcement of dipole fields [15].

NBA has a higher dielectric constant than BA due to the presence of the electron withdrawing nitro group where large orientational polarization is resulted with the existence of a chain type of association and the presence of molecular units of large dipole moments. PB has a lower dielectric constant than TU since $\varepsilon$ decreases as steric hindrance effect increases. For the complexes, the dielectric constant $(\varepsilon)$ is higher than that for the ligands, also, as the atomic number of the metal increases, the dielectric constant $(\varepsilon)$ and the loss tangent $(\tan \delta)$ are mostly decreased to block the charge distribution.

The dielectric constants and the loss tangents of some ligands and their complex solutions are high that the dielectrometer equipment can't measure them satisfactorily due to the higher polarizability (Table 1). The loss tangent $(\tan \delta$ ) values increase by increasing the temperature due to a decrease in viscosity, which exerts an increase of the dipole rotation and the polarization of the material. The dielectric material usually contains traces of charges as impurities, where the activity increased by increasing the temperature.

The electrical conductivity $\sigma\left(\Omega^{-1} \mathrm{~cm}^{-1}\right)$ is given by [16]:

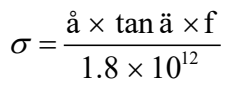

where $\varepsilon$ is the dielectric constant, $\tan \delta$ is the loss tangent, and $\mathrm{f}$ is the frequency of the instrument $\left(3 \times 10^{6} \mathrm{~Hz}\right)$.

The dielectric conductivity sums overall dissipative effects, which may represent the conductivity caused by migrating charge carriers and related to an energy loss associated with a frequency dependence of $\varepsilon$. The values of electrical conductivity $(\sigma)$ for solutions of $10^{-3} \mathrm{M}-$ ligands and their complexes at different temperatures $\left(25-50^{\circ} \mathrm{C}\right)$ are given in Table 2.

The electrical conductivity of solutions at a given frequency varies exponentially with the absolute temperature according to the Arrhenius relation [17]. The values of $\Delta \mathrm{E}$ and $\sigma_{\mathrm{o}}$ for solutions of $10^{-3} \mathrm{M}$-ligands and their complexes are given in Table 3 . As the atomic number of the metal increases, the electrical conductivity regularly decreased and the activation energy $(\Delta \mathrm{E})$ of the complexes decreased in an irregular trend. 
<smiles>O=C1CC(=O)NC(=O)N1</smiles><smiles>O=C1NC(=O)C([N+](=O)[O-])C(=O)N1</smiles><smiles>CCC1(c2ccccc2)C(=O)NC(=O)NC1=O</smiles><smiles>O=c1cc[nH]c(=O)[nH]1</smiles>

Figure 1. Ligands a) BA (b) NBA (c) PB (d) TU.

Table 1. Values of dielectric constant $(\varepsilon)$ and loss tangent $(\tan \delta)$ for solutions of $10^{-3} \mathrm{M}$-ligands and their complexes at different temperatures $\left(25-50^{\circ} \mathrm{C}\right)$ and media (a) In $50 \%(\mathrm{v} / \mathrm{v}) \mathrm{MeOH}-$ water

\begin{tabular}{|c|c|c|c|c|c|c|c|}
\hline \multicolumn{2}{|l|}{ Compound } & $25^{\circ} \mathrm{C}$ & $30^{\circ} \mathrm{C}$ & $35^{\circ} \mathrm{C}$ & $40^{\circ} \mathrm{C}$ & $45^{\circ} \mathrm{C}$ & $50^{\circ} \mathrm{C}$ \\
\hline \multirow[t]{2}{*}{ BA } & $\varepsilon$ & 60.89 & 61.04 & 61.48 & 62.03 & 62.36 & 62.58 \\
\hline & $\tan \delta$ & 0.26 & 0.28 & 0.31 & 0.33 & 0.35 & 0.38 \\
\hline \multirow[t]{2}{*}{$\mathrm{Zn}^{2+} / \mathbf{B A}$} & $\varepsilon$ & 61.59 & 62.36 & 63.35 & 64.34 & 65.33 & 66.54 \\
\hline & $\tan \delta$ & 0.30 & 0.34 & 0.37 & 0.39 & 0.42 & 0.44 \\
\hline \multirow[t]{2}{*}{$\mathrm{Cu}^{2+} / \mathbf{B A}$} & $\varepsilon$ & 63.79 & 65.33 & 66.43 & 67.53 & 68.63 & 69.73 \\
\hline & $\tan \delta$ & 0.33 & 0.37 & 0.40 & 0.43 & & \\
\hline \multirow[t]{2}{*}{$\mathrm{Co}^{2+} / \mathbf{B A}$} & $\varepsilon$ & 64.56 & 65.77 & 66.98 & 69.18 & 70.93 & 72.58 \\
\hline & $\tan \delta$ & 0.38 & 0.42 & & & & \\
\hline $\mathrm{Fe}^{3+} / \mathbf{B A}$ & $\varepsilon$ & 82.81 & 85.56 & 90.40 & 94.03 & 100.62 & 105.02 \\
\hline NBA & $\varepsilon$ & 79.62 & 83.58 & 88.31 & 93.26 & 98.42 & 104.03 \\
\hline $\mathrm{Zn}^{2+} / \mathrm{NBA}$ & $\varepsilon$ & 81.93 & 86.11 & 90.62 & 95.68 & 100.95 & 106.78 \\
\hline $\mathrm{Cu}^{2+} / \mathrm{NBA}$ & $\varepsilon$ & 87.43 & 90.18 & 95.68 & 101.17 & 106.67 & 110.52 \\
\hline $\mathrm{Co}^{2+} / \mathrm{NBA}$ & $\varepsilon$ & 93.81 & 102.60 & 111.51 & 120.97 & 131.85 & 144.50 \\
\hline $\mathrm{Fe}^{3+} / \mathbf{N B A}$ & $\varepsilon$ & 116.79 & 128.11 & 148.46 & 173.42 & & \\
\hline
\end{tabular}

b) In $50 \%(v / v)$ dioxane-water

\begin{tabular}{|c|c|c|c|c|c|c|c|}
\hline \multicolumn{2}{|c|}{ Compound $\quad$ Temperature } & \multirow{2}{*}{$\begin{array}{l}\mathbf{2 5}^{\circ} \mathbf{C} \\
37.13\end{array}$} & \multirow{2}{*}{$\begin{array}{l}\mathbf{3 0}^{\circ} \mathbf{C} \\
37.49\end{array}$} & \multirow{2}{*}{$\begin{array}{l}\mathbf{3 5}^{\circ} \mathbf{C} \\
37.73\end{array}$} & \multirow{2}{*}{$\begin{array}{l}\mathbf{4 0}^{\circ} \mathrm{C} \\
38.21\end{array}$} & \multirow{2}{*}{$\begin{array}{l}\mathbf{4 5}^{\circ} \mathrm{C} \\
38.33\end{array}$} & \multirow{2}{*}{$\begin{array}{l}\mathbf{5 0}^{\circ} \mathbf{C} \\
38.21 \\
\end{array}$} \\
\hline PB & $\varepsilon$ & & & & & & \\
\hline & $\tan \delta$ & 0.086 & 0.10 & 0.11 & 0.12 & 0.13 & 0.15 \\
\hline \multirow[t]{2}{*}{$\mathrm{Zn}^{2+} / \mathbf{P B}$} & $\varepsilon$ & 37.49 & 38.21 & 38.33 & 38.57 & 38.81 & 38.93 \\
\hline & $\tan \delta$ & 0.13 & 0.15 & 0.17 & 0.19 & 0.20 & 0.20 \\
\hline \multirow[t]{2}{*}{$\mathrm{Cu}^{2+} / \mathbf{P B}$} & $\varepsilon$ & 37.49 & 37.97 & 38.45 & 38.93 & 40.25 & 40.85 \\
\hline & $\tan \delta$ & 0.16 & 0.18 & 0.20 & 0.22 & 0.25 & 0.29 \\
\hline \multirow[t]{2}{*}{$\mathrm{Co}^{2+} / \mathbf{P B}$} & $\varepsilon$ & 44.21 & 44.81 & 45.53 & 46.61 & 47.81 & 48.41 \\
\hline & $\tan \delta$ & 0.34 & 0.36 & 0.40 & 0.42 & 0.44 & 0.48 \\
\hline $\mathrm{Fe}^{3+} / \mathrm{PB}$ & $\varepsilon$ & 55.50 & 58.02 & 60.78 & 64.50 & 68.46 & 71.82 \\
\hline \multirow[t]{2}{*}{$\mathbf{T U}$} & $\varepsilon$ & 46.37 & 47.69 & 49.13 & 51.29 & 55.50 & 65.70 \\
\hline & $\tan \delta$ & 0.46 & 0.50 & 0.54 & 0.59 & & \\
\hline \multirow[t]{2}{*}{$\mathrm{Zn}^{2+} / \mathrm{TU}$} & $\varepsilon$ & 48.89 & 51.29 & 54.05 & 58.74 & 63.66 & 66.90 \\
\hline & $\tan \delta$ & 0.43 & 0.48 & 0.54 & & & \\
\hline $\mathrm{Cu}^{2+} / \mathrm{TU}$ & $\varepsilon$ & 57.90 & 60.30 & 62.22 & 65.82 & 68.22 & 70.50 \\
\hline $\mathrm{Co}^{2+} / \mathrm{TU}$ & $\varepsilon$ & 70.50 & 75.42 & 80.22 & 86.58 & 92.47 & 101.59 \\
\hline $\mathrm{Fe}^{3+} / \mathrm{TU}$ & $\varepsilon$ & 74.22 & 80.10 & 86.46 & 95.11 & 104.23 & 117.43 \\
\hline
\end{tabular}

Table 2. Values of a.c. electrical conductivity $\left(\sigma 10^{5}\right)\left(\Omega^{-1} \mathrm{~cm}^{-1}\right)$ for solutions of $10^{-3} \mathrm{M}$-ligands and their complexes at different temperatures $\left(25-50^{\circ} \mathrm{C}\right)$.

\begin{tabular}{|c|c|c|c|c|c|c|}
\hline Compound Temperature & $25^{\circ} \mathrm{C}$ & $30^{\circ} \mathrm{C}$ & $35^{\circ} \mathrm{C}$ & $40^{\circ} \mathrm{C}$ & $45^{\circ} \mathrm{C}$ & $50^{\circ} \mathrm{C}$ \\
\hline & \multicolumn{6}{|c|}{ 50\%(v/v) MeOH-water } \\
\hline BA & 2.60 & 2.82 & 3.16 & 3.43 & 3.69 & 3.96 \\
\hline $\mathrm{Zn}^{2+} / \mathbf{B A}$ & 3.10 & 3.52 & 3.88 & 4.22 & 4.58 & 4.88 \\
\hline $\mathrm{Cu}^{2+} / \mathbf{B A}$ & 3.55 & 3.98 & 4.43 & 4.87 & & \\
\hline \multirow[t]{2}{*}{$\mathrm{Co}^{2+} / \mathbf{B A}$} & 4.04 & 4.65 & & & & \\
\hline & \multicolumn{6}{|c|}{$50 \%(v / v)$ dioxane-water } \\
\hline PB & 0.53 & 0.61 & 0.71 & 0.75 & 0.81 & 0.94 \\
\hline $\mathrm{Zn}^{2+} / \mathbf{P B}$ & 0.81 & 0.94 & 1.10 & 1.20 & 1.29 & 1.31 \\
\hline $\mathrm{Cu}^{2+} / \mathbf{P B}$ & 0.98 & 1.14 & 1.26 & 1.45 & 1.71 & 1.96 \\
\hline $\mathrm{Co}^{2+} / \mathrm{PB}$ & 2.49 & 2.66 & 3.03 & 3.27 & 3.47 & 3.85 \\
\hline TU & 3.56 & 4.00 & 4.41 & 5.07 & & \\
\hline $\mathrm{Zn}^{2+} / \mathrm{TU}$ & 3.51 & 4.14 & 4.83 & & & \\
\hline
\end{tabular}




\section{Molar conductance $\Lambda_{\mathrm{m}}$ measurements}

The electrolytic conductors have a transfer of material associated with the passage of an electric current in the solution. The molar conductance $\Lambda_{\mathrm{m}}\left(\Omega^{-1} \mathrm{~cm}^{2} \mathrm{~mol}^{-1}\right)$ is given as follows [18]:

$$
\ddot{\mathbf{E}}_{m}=\frac{£ 000}{\mathrm{c}}
$$

where $\kappa$ is the specific conductance of solution, $\kappa\left(\Omega^{-1} \mathrm{~cm}^{-1}\right)=K / R$, $\mathrm{K}$ is the cell constant equals $0.99 \mathrm{~cm}^{-1}$ at $25^{\circ} \mathrm{C}, \mathrm{R}$ is the resistance of an electrolytic solution and $\mathrm{c}$ is the molar concentration of solution.

The molar conductance measurement data for the electrolytic solutions of $\mathrm{BA}, \mathrm{NBA}, \mathrm{PB}$ and $\mathrm{TU}$ at $25^{\circ} \mathrm{C}$ are plotted against different concentrations. Figure 2 gave Kolarausch $\Lambda_{\mathrm{m}}-C_{1}=$ relationship for ligand solutions indicated the presence of two behaviors. The compounds BA, PB and TU are of weak electrolytic in nature with low molar conductance until very high dilutions, it increases suddenly. On the other hand, the NBA exhibits high values of molar conductance over the whole concentrations range which is considered to have strong electrolytic nature due to the presence of withdrawing nitro group.

The molar conductance $\Lambda_{\mathrm{m}}$ for the investigated electrolytes increases by increasing temperature, in accordance with the increase of ionic mobility where the rule of solvent play an important part in migration of ions, Table 4.

However, the $\Lambda_{\mathrm{m}}-\varepsilon$ relations for solutions of ligands and their complexes at different temperatures $\left(25-45^{\circ} \mathrm{C}\right)$ are given in Table 5 . The molar conductance $\Lambda_{\mathrm{m}}$ of electrolytic solutions mostly increased as the dielectric constant $\varepsilon$ of the solutions increased, due to the increase of the ionic mobility.

\section{Conclusion}

The values of $\varepsilon, \tan \delta, \sigma$ for solutions of ligands and their complexes are increased by increasing temperature. NBA has a higher dielectric constant value than BA due to the presence of the electron withdrawing nitro group with large orientational polarization. PB has a lower dielectric constant value than TU since $\varepsilon$ decreases as the steric hindrance effect increases. The BA, PB and TU ligands are of weak electrolytic nature, while NBA is of strong electrolytic behavior. The change of medium from $50 \%(\mathrm{v} / \mathrm{v}) \mathrm{MeOH}$-water to $50 \%(\mathrm{v} / \mathrm{v})$ dioxanewater showed a remarkable effect in the behavior of ligands and complex properties.

Table 3. The values of $\Delta \mathrm{E}$ and $\sigma_{\mathrm{o}}$ for solutions of $10^{-3} \mathrm{M}$-ligands and their complexes.

\begin{tabular}{|c|c|c|}
\hline Compound & $\Delta \mathbf{E}\left(\mathrm{kJ} \mathrm{mol}^{-1}\right)$ & $\sigma_{0}$ \\
\hline & $\mathbf{5 0 \% ( v / v ) ~ M e O H - w a t e r ~}$ & \\
\hline BA & 13.6607 & 0.0065 \\
\hline $\mathbf{Z n}^{2+} / \mathbf{B A}$ & 14.4415 & 0.0108 \\
\hline $\mathrm{Cu}^{2+} / \mathbf{B A}$ & 16.3655 & 0.0263 \\
\hline \multirow[t]{2}{*}{$\mathrm{Co}^{2+} / \mathrm{BA}$} & 21.1829 & 0.2085 \\
\hline & $50 \%(v / v)$ dioxane-water & \\
\hline PB & 17.0156 & 0.0052 \\
\hline $\mathrm{Zn}^{2+} / \mathbf{P B}$ & 15.8475 & 0.0051 \\
\hline $\mathrm{Cu}^{2+} / \mathrm{PB}$ & 22.0792 & 0.0719 \\
\hline $\mathrm{Co}^{2+} / \mathrm{PB}$ & 13.9160 & 0.0068 \\
\hline TU & 18.0408 & 0.0515 \\
\hline $\mathrm{Zn}^{2+} / \mathrm{TU}$ & 24.2642 & 0.6294 \\
\hline
\end{tabular}

Table 4. Molar conductance $\Lambda_{\mathrm{m}}$ data for solutions of $10^{-3} \mathrm{M}$-ligands and their complexes at different temperatures.

\begin{tabular}{|c|c|c|c|c|c|c|c|c|c|}
\hline \multirow{2}{*}{ Compound Temperature } & \multicolumn{3}{|c|}{$25^{\circ} \mathrm{C}$} & \multicolumn{3}{|c|}{$35^{\circ} \mathrm{C}$} & \multicolumn{3}{|c|}{$45^{\circ} \mathrm{C}$} \\
\hline & $10^{6} / \mathrm{R}$ & $10^{5} \kappa$ & $\Lambda_{\mathrm{m}}$ & $10^{6} / \mathbf{R}$ & $10^{5} \kappa$ & $\Lambda_{\mathrm{m}}$ & $10^{6} / \mathrm{R}$ & $10^{5} \kappa$ & $\Lambda_{\mathrm{m}}$ \\
\hline BA & 68.0 & 6.73 & 67.32 & 71.7 & 7.10 & 70.98 & 73.1 & 7.24 & 72.37 \\
\hline $\mathbf{Z n}^{2+} / \mathbf{B A}$ & 87.8 & 8.69 & 72.44 & 89.8 & 8.89 & 74.09 & 93.0 & 9.21 & 76.73 \\
\hline $\mathrm{Cu}^{2+} / \mathbf{B A}$ & 85.8 & 8.49 & 70.79 & 86.2 & 8.53 & 71.12 & 88.9 & 8.80 & 73.34 \\
\hline $\mathrm{Co}^{2+} / \mathbf{B A}$ & 94.0 & 9.31 & 77.55 & 96.6 & 9.56 & 79.70 & 100.1 & 9.91 & 82.58 \\
\hline $\mathbf{F e}^{3+} / \mathbf{B A}$ & 125.2 & 12.39 & 103.29 & 132.9 & 13.16 & 109.64 & 136.2 & 13.48 & 112.37 \\
\hline NBA & 137.6 & 13.62 & 136.22 & 141.0 & 13.96 & 139.59 & 147.5 & 14.60 & 146.03 \\
\hline $\mathrm{Zn}^{2+} / \mathbf{N B A}$ & 142.3 & 14.09 & 117.40 & 144.0 & 14.26 & 118.80 & 148.0 & 14.65 & 122.10 \\
\hline $\mathrm{Cu}^{2+} / \mathbf{N B A}$ & 130.6 & 12.93 & 107.75 & 132.0 & 13.07 & 108.90 & 134.2 & 13.29 & 110.72 \\
\hline $\mathrm{Co}^{2+} / \mathrm{NBA}$ & 158.3 & 15.67 & 130.60 & 162.4 & 16.08 & 133.98 & 167.0 & 16.53 & 137.78 \\
\hline $\mathrm{Fe}^{3+} / \mathrm{NBA}$ & 191.0 & 18.91 & 157.58 & 197.0 & 19.50 & 162.53 & 206.0 & 20.39 & 169.95 \\
\hline PB & 44.3 & 4.39 & 43.86 & 47.7 & 4.72 & 47.22 & 50.0 & 4.95 & 49.50 \\
\hline $\mathrm{Zn}^{2+} / \mathbf{P B}$ & 48.2 & 4.77 & 39.77 & 52.1 & 5.16 & 42.98 & 53.7 & 5.32 & 44.30 \\
\hline $\mathrm{Cu}^{2+} / \mathbf{P B}$ & 48.6 & 4.81 & 40.10 & 50.7 & 5.02 & 41.83 & 54.3 & 5.38 & 44.80 \\
\hline $\mathrm{Co}^{2+} / \mathrm{PB}$ & 65.4 & 6.47 & 53.96 & 68.6 & 6.79 & 56.60 & 73.0 & 7.23 & 60.23 \\
\hline $\mathrm{Fe}^{3+} / \mathrm{PB}$ & 120.8 & 11.96 & 99.66 & 121.6 & 12.04 & 100.32 & 125.2 & 12.39 & 103.29 \\
\hline TU & 41.4 & 4.10 & 40.99 & 42.5 & 4.21 & 42.08 & 45.5 & 4.50 & 45.05 \\
\hline $\mathrm{Zn}^{2+} / \mathbf{T U}$ & 44.0 & 4.36 & 36.30 & 46.6 & 4.61 & 38.45 & 51.6 & 5.11 & 42.57 \\
\hline $\mathrm{Cu}^{2+} / \mathrm{TU}$ & 61.5 & 6.09 & 50.74 & 65.7 & 6.50 & 54.20 & 71.8 & 7.11 & 59.24 \\
\hline $\mathrm{Co}^{2+} / \mathrm{TU}$ & 62.5 & 6.19 & 51.56 & 68.2 & 6.75 & 56.27 & 76.1 & 7.53 & 62.78 \\
\hline $\mathrm{Fe}^{3+} / \mathrm{TU}$ & 121.5 & 12.03 & 100.24 & 127.5 & 12.62 & 105.19 & 131.0 & 12.97 & 108.08 \\
\hline
\end{tabular}


Table 5. The values of $\varepsilon$ and $\Lambda_{\mathrm{m}}\left(\Omega^{-1} \mathrm{~cm}^{2} \mathrm{~mol}^{-1}\right)$ for solutions of ligands and their complexes at different temperatures.

\begin{tabular}{|c|c|c|c|c|c|c|}
\hline \multirow{2}{*}{ Compound Temperature } & \multicolumn{2}{|c|}{$25^{\circ} \mathrm{C}$} & \multicolumn{2}{|c|}{$35^{\circ} \mathrm{C}$} & \multicolumn{2}{|c|}{$45^{\circ} \mathrm{C}$} \\
\hline & $\varepsilon$ & $\Lambda_{\mathrm{m}}$ & $\varepsilon$ & $\Lambda_{\mathrm{m}}$ & $\varepsilon$ & $\Lambda_{\mathrm{m}}$ \\
\hline BA & 60.82 & 67.32 & 61.48 & 70.98 & 62.36 & 72.37 \\
\hline NBA & 79.62 & 136.22 & 88.31 & 139.59 & 98.42 & 146.03 \\
\hline PB & 37.13 & 43.86 & 37.73 & 47.22 & 38.33 & 49.50 \\
\hline TU & 46.37 & 40.99 & 49.13 & 42.08 & 55.50 & 45.05 \\
\hline $\mathrm{Zn}^{2+} / \mathbf{B A}$ & 61.59 & 72.44 & 63.35 & 74.09 & 65.33 & 76.73 \\
\hline $\mathrm{Zn}^{2+} / \mathrm{NBA}$ & 81.93 & 117.40 & 90.62 & 118.80 & 100.95 & 122.10 \\
\hline $\mathrm{Zn}^{2+} / \mathbf{P B}$ & 37.49 & 39.77 & 38.33 & 42.98 & 38.81 & 44.30 \\
\hline $\mathrm{Zn}^{2+} / \mathrm{TU}$ & 48.89 & 36.30 & 54.05 & 38.45 & 63.66 & 42.57 \\
\hline $\mathrm{Cu}^{2+} / \mathbf{B A}$ & 63.79 & 70.79 & 66.43 & 71.12 & 68.63 & 73.34 \\
\hline $\mathrm{Cu}^{2+} / \mathrm{NBA}$ & 87.43 & 107.75 & 95.68 & 108.90 & 106.67 & 110.72 \\
\hline $\mathrm{Cu}^{2+} / \mathbf{P B}$ & 37.49 & 40.10 & 38.45 & 41.83 & 40.25 & 44.80 \\
\hline $\mathrm{Cu}^{2+} / \mathrm{TU}$ & 57.90 & 50.74 & 62.22 & 54.20 & 68.22 & 59.24 \\
\hline $\mathrm{Co}^{2+} / \mathrm{BA}$ & 64.56 & 77.55 & 66.98 & 79.70 & 70.93 & 82.58 \\
\hline $\mathrm{Co}^{2+} / \mathrm{NBA}$ & 93.81 & 130.60 & 111.51 & 133.98 & 131.85 & 137.78 \\
\hline $\mathrm{Co}^{2+} / \mathrm{PB}$ & 44.21 & 53.96 & 45.53 & 56.60 & 47.81 & 60.23 \\
\hline $\mathrm{Co}^{2+} / \mathrm{TU}$ & 70.50 & 51.56 & 80.22 & 56.27 & 92.47 & 62.78 \\
\hline $\mathrm{Fe}^{3+} / \mathbf{B A}$ & 82.81 & 103.29 & 90.40 & 109.64 & 100.62 & 112.37 \\
\hline $\mathrm{Fe}^{3+} / \mathrm{NBA}$ & 116.79 & 157.58 & 148.46 & 162.53 & & 169.95 \\
\hline $\mathrm{Fe}^{3+} / \mathrm{PB}$ & 55.50 & 99.66 & 60.78 & 100.32 & 68.46 & 103.29 \\
\hline $\mathrm{Fe}^{3+} / \mathrm{TU}$ & 74.22 & 100.24 & 86.46 & 105.19 & 104.23 & 108.08 \\
\hline
\end{tabular}

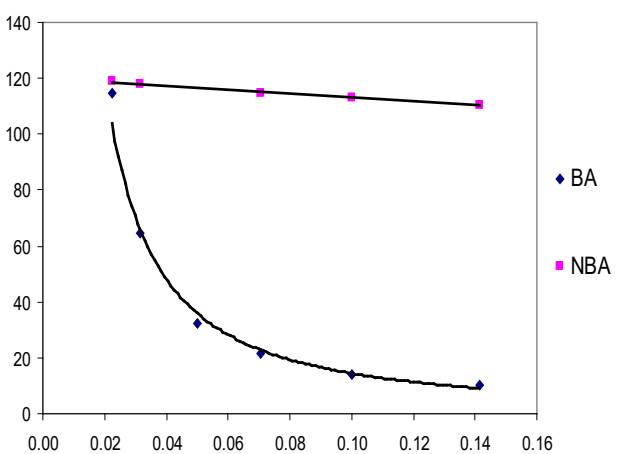

(a)

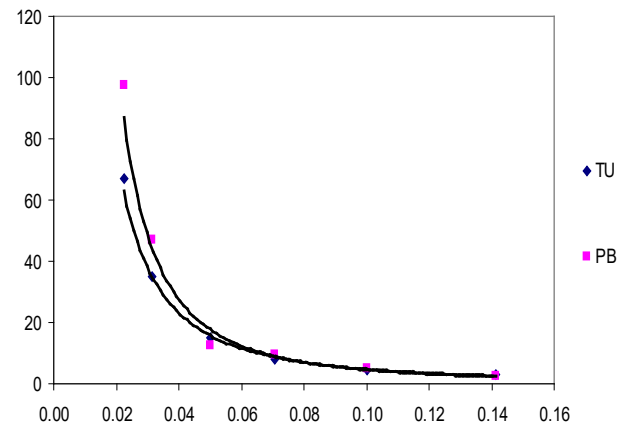

(b)

Figure 2. Molar conductance vs. $\sqrt{\mathrm{c}}$ for (BA, NBA), (PB and TU) at $25^{\circ} \mathrm{C}$ in (a) $50 \%(\mathrm{v} / \mathrm{v}) \mathrm{MeOH}$-water and (b) $50 \%(\mathrm{v} / \mathrm{v})$ dioxane-water solutions.

\section{References}

1. Smyth CP (1936) The Dielectric Constants of Solids and Molecular Rotation. Chem Rev 19: 329-361.

2. Murphy EJ, Morgan SO (1939) The dielectric properties of insulating materials, III alternating and direct current conductivity. J Bell System Tech 18: 502-537.

3. Masoud MS, Abou El-Enein SA, Kamel HM (2002) Structural chemistry and therma properties of some pyrimidine complexes. Indian J Chem 41: 297-303.

4. Masoud MS, Hammud HH, Beidas H (2002) Dissociation constants of eriochrome black $\mathrm{T}$ and eriochrome blue black RC indicators and the formation constants of their complexes with $\mathrm{Fe}(\mathrm{III}), \mathrm{Co}(\mathrm{II}), \mathrm{Ni}(\mathrm{II}), \mathrm{Cu}(\mathrm{II}), \mathrm{Zn}$ (II), $\mathrm{Cd}(\mathrm{II}), \mathrm{Hg}(\mathrm{II})$, and $\mathrm{Pb}(\mathrm{II})$, under different temperatures and in presence of different solvents. Thermchim Acta 381: 119-131.

5. Masoud MS, Ghonaim A KH, Ahmed RH, Abou El-Enein SA, Mahmoud AA (2002) Ligating Properties of 5-Nitrobarbituric Acid. J Coord Chem 55: 79-105.

6. Masoud MS, Mohamed GB, Abdul-Razek YH, Ali AE, Khairy FN (2002) studies on some thiazolylazo compounds and their cobalt, nickel, and copper complexes. Spectrosc Lett 35: 377-413.

7. Masoud MS, Abou El-Enein SA, Ayad ME, Goher AS (2004) Spectral and magnetic properties of phenylazo-6-aminouracil complexes. Spectrochim Acta 60: 77-87.

8. Masoud MS, Khalil EA, Hindawey AM, Ali AE, Fawzy EM (2004) Spectroscopic studies on some azo compounds and their cobalt, nickel and copper complexes. Spectrochim Acta 60A: 2807-2817.

9. Masoud MS, Khalil EA, El-Khatib A, Mohamed Sh Sh (2009) Conducting Properties of Some Biomaterials at Different Temperatures and $\gamma$-Irradiation. Polish J Chem 83: 2189-2193.
10. Masoud MS, Khalil EA, Ramadan AM, Mokhtar SA, Hafez OF (2014) Spectral, Ligating Properties, and Electrical Conductivity of Some Azo-Nitroso Metal Complexes. Synthesis and reactivity in inorganic and metal-organic and Nano-Metal chemistry 44: 402-412.

11. Szabo G, Nagy B (1962) A Novel Instrument for Dielectric Measurements with Applications to Chemical Analysis. J Scientific Instruments 36: 414

12. Daniel VV (1967) Dielctric Relaxation. Academic Press, London And New York.

13. Tareev B (1979) Physics of Dielectric Materials. Mir Publisher, Moscow.

14. Akerlof G (1932) Dielectric constants of some organic solvent-water mixtures at various temperatures. J Am Chem Soc 54: 4125-4139.

15. Alssandro D (1974) Dielectric constants of 1-pentanol-water mixtures at 25.deg. J Phys Chem 78: 652.

16. Bassyoni FM (1981) Ph.D. Thesis, Egypt, pp: 176

17. Olson DC, Mayweg VP, Schrauzer GN (1966) Polarographic Study of Coordination Compounds with Delocalized Ground States. Substituent Effects in Bis- and Trisdithiodiketone Complexes of Transition Metals. J Am Chem Soc 88: 4876-4882.

18. Levine N (2002) Physical Chemistry. (5th Ed.) McGraw-Hill, New York.

Copyright: (C2017 Masoud MS. This is an open-access article distributed under the terms of the Creative Commons Attribution License, which permits unrestricted use, distribution, and reproduction in any medium, provided the original author and source are credited. 